\title{
The Effect Of Non-Audit Services On Independent Auditor Judgment
}

Tim Kizirian, Ph.D., Chico State University, USA

Ruben Sargsyan, Ph.D., Chico State University, USA

\begin{abstract}
This study examines the effects of non-audit services on auditors' risk and materiality judgments. The results revealed a significantly negative association between non-audit services and auditors' risk judgments, but only for services involving financial information system design and implementation. The auditors did not change their risk judgments for non-audit services with less audit relevance. Non-audit services had an insignificant effect on auditors' materiality judgments. We conclude that non-audit services did not cause an inappropriate bias in auditor judgment.
\end{abstract}

Keywor ds: Independent Auditor Judgment; Non-Audit Services; Sarbanes-Oxley

\section{INTRODUCTION}

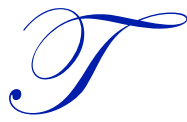

he second field work standard in auditing requires auditors to maintain an independent mental attitude in all matters related to the audit engagement. To increase conformance with the standard, policy makers have instituted rules that limit economic relationships between auditors and their clients. Most notably, Section 201 of the Sarbanes-Oxley Act of 2002 (SOX 201) prohibited auditing firms from providing various non-audit services to audit clients. ${ }^{1}$ Policy makers apparently accepted the empirical proposition that, before the ban by SOX 201, a firm's provision of non-audit services to audit clients caused an intentional or an unintentional bias in its auditors' mental attitude, impairing independence and raising audit risk. Despite a lengthy debate on whether non-audit services generally affected auditor independence (Panel on Audit Effectiveness 2000; Securities and Exchange Commission 2000), there was minimal empirical research on this issue prior to SOX 201. Instead, policy makers responded to a priori arguments (Levitt 2000) and a few well-known cases in which an audit failure coincided with the firm's provision of non-audit services (Healy and Palepu 2003).

Empirical researchers who examine the association between non-audit services and auditor independence face three problems. First, independence is an unobservable mental state, so that empirical inferences about the effects of nonaudit services require observations of auditor behavior or its consequences. More direct and valid inferences about independence result from observing auditor behavior rather than its consequences, because extraneous factors influence the latter (Nelson 2004). For example, observing auditors' propensity to issue qualified reports for financially distressed clients permits a more direct inference than does observing discretionary accruals in audited financial statements or restatements of past audited financial statements. Second, independence pertains to all matters related to the audit engagement, and not just the audit report. Observing only audit reports misses the possibility that non-audit services impair independence with respect to audit planning and inappropriately decrease the probability of detecting an existing misstatement. Audit quality depends on both the probability of detecting an existing misstatement and the probability of reporting a detected misstatement. Third, relevant data about non -audit service fees were not publicly available until 2000 (Securities and Exchange Commission 2000). ${ }^{2}$ Most research on auditor independence has relied on non-audit service data from 2000 and subsequent years.

\footnotetext{
${ }^{1}$ SOX 201 prohibited auditing firms from providing the following non-audit services to audit clients, contemporaneously wit h the audit: (1) bookkeeping and other services related to accounting records and financial statements: (2) financial information system design and implementation; (3) appraisal or valuation services; (4) actuarial services; (5) internal audit outsourcing; (6) management f un ction or h um an resources; (7) broker, investment advisor, or investment banking; (8) legal services or expert serv ices unrelated to the audit; and (9) other services that the Public Company Accounting Oversight Board determines to be impermissible. SOX 201 also required pre-approval of allowed non-audit services, including tax services, by the client's audit committee.

${ }^{2}$ The SEC required such disclosure in a much earlier time (1978-1981).
} 
This study contributes to the literature on auditor independence by examining the effects of a firm's provision of non-audit services on its auditors' planning judgments, based on archival data from the firm's work papers for audit engagements in the late 1990s. This data set included auditors' planning materiality and risk judgments for revenue, as well as fees for two categories of non-audit services: financial information system design and implementation, and other non-audit services (e.g., negotiation advice and technology tracking). This categorization is important, because an improvement in the audit client's financial information system is a cue that reasonably lowers auditors' risk judgments, whereas non-audit services with less audit relevance should not. The results showed a significantly negative association between the firm's provision of non-audit services and its auditors' risk judgments, but only for services involving financial information system design and implementation. Neither category of non -audit services significantly affected auditors' materiality judgments. Our interpretation is that the firm's provision of non-audit services did not cause an inappropriate bias in its auditors' planning judgments. Our empirical evidence contradicts the proposition that, before the ban by SOX 201, non-audit services impaired auditor independence. Going forward, we encourage regulators such as the Public Company Accounting Oversight Board (PCAOB) to base policy on empirical research in the tradition of normative-positive economics.

\section{BACKGROUND AND HYPOTHESES}

\section{Background}

The normative-positive distinction is a major concept in the history of economic thought (Blaug 1992; Friedman 1953), and is well-known to empirical researchers in accounting (Abdel-khalik and Ajinkya 1979). The distinction suggests a bilateral and continuing relationship between policy makers and empirical researchers. On the one hand, policy makers should base their normative decisions on the results of systematic empirical testing of relevant propositions. The normative decision to ban auditing firms from providing non-audit services should be based on empirical evidence about the proposition that non-audit services generally impaired auditor independence. On the other hand, researchers should design their tests so that the empirical evidence is relevant to policy, but also is objective. Empirical tests of whether non-audit services generally impaired auditor independence should not be colored by researchers' opinions about the appropriateness of SOX 201. The relationship is continuing, in that empirical researchers can contribute both ex ante and ex post evidence regarding specific policy. The ex ante evidence facilitates policy formation; whereas the ex post evidence facilitates policy change when appropriate. Despite the minimal ex ante evidence in the formation of SOX 201, empirical researchers still can provide useful ex post evidence to the PCAOB and other regulators.

The ban by SOX 201 followed an extensive public debate on whether auditing firms should be allowed to provide non-audit services to audit clients (Panel on Audit Effectiveness 2000; Securities and Exchange Commission 2000). The debate boiled down to two arguments. On the plus side, there was an economy of scope or "knowledge spillover" for auditing firms that provided certain non-audit services to audit clients. By providing such services, auditing firms acquired client-specific knowledge that enhanced audit effectiveness and efficiency. In addition, auditors were in a position to identify problems with the client's accounting and control system, and to remedy such problems. On the minus side, there was a conflict of interest for auditing firms that provided non-audit services to audit clients. Such firms apparently served two masters. Regarding audit services, shareholders were the master. A purpose of the audit was to report to shareholders about management's performance. This purpose was ill-served when the auditor affirmed financial statements that inflated performance. Regarding non-audit services, management was the master. Management decided whether to hire the firm to provide non-audit services and negotiated the fee for such services. The concern was that management used non-audit services as an incentive that pressed the auditor to reach judgments favoring the client, including the affirmation of financial statements that inflated performance.

Unlike the dearth of policy-relevant research prior to SOX 201, the literature contains many recent studies on nonaudit services and auditor independence, most of which relied on data from 2000 and subsequent years. To distinguish our study, Figure 1 shows four ways in which empirical researchers can observe the effects of a firm's provision of non-audit services on auditor independence. The audit process consists of a discovery phase and reporting phase. In the discovery phase, auditors collect information about the client, plan and perform test procedures, evaluate the resulting evidence, and assess whether a misstatement exists in the client's financial 
statements. In the reporting phase, auditors discuss detected misstatements with the client, reach an agreement about the adjustment to the financial statements, and report on whether the adjusted financial statements conform to generally accepted accounting principles. The client makes the audited financial statements and audit report available to external users.

Figure 1. Audit Process, Auditor Independence, and Non-audit Services

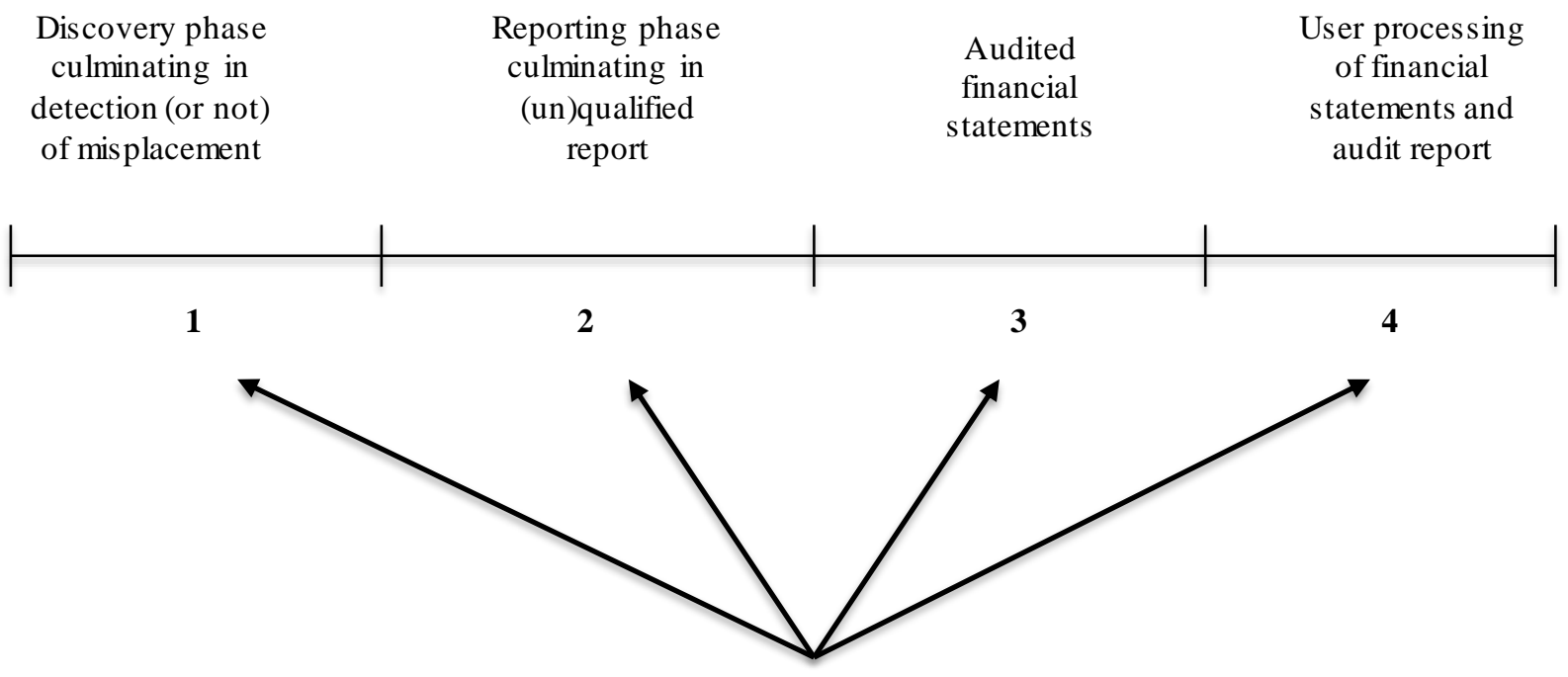

Auditor independence

$$
\uparrow
$$

Firm's provision of non-audit services

The early literature on auditor independence stressed the possibility of an intentional bias in the reporting of a detected misstatement (DeAngelo 1981). Audit quality depends on the joint probability that auditors discover an existing misstatement and report the detected misstatement.

The probability that a given auditor will discover a breach depends on the auditor's technological capabilities, the audit procedure employed on a given audit, the extent of testing, etc. The conditional probability of reporting a detected breach is a measure of an auditor's independence from a given client (DeAngelo 1981, p. 186).

In our view, this measure is too narrow. Independence requires unbiased auditor judgment in the discovery phase as well as reporting phase. Even if the conditional probability of reporting a detected misstatement is one, audit quality suffers when impaired independence decreases the probability of detecting an existing misstatement. This consideration motivates our focus on the effect of a firm's provision of non-audit services on its auditors' risk and materiality judgments in the discovery phase (link 1 in Figure 1).

In contrast, past studies focused on the reporting phase (link 2), accruals in audited financial statements and restatements of past audited financial statements (link 3), and users' processing of audited financial statements and disclosures about auditors' fees (link 4). Regarding link 2, DeFond, Raghunandan, and Subramanyam (2002) examined a set of distressed companies from 2000, and found no association between auditors' propensity to issue unfavorable going-concern reports and the fee ratio of non-audit fees to total fees. DeFond et al. (2002) also found that distressed companies with a higher audit fee were more likely to have an unfavorable go ing-concern report. Geiger and Rama (2003) reported similar results. 
Regarding link 3, Frankel, Johnson, and Nelson (2002) examined data from 2001, and found significantly positive associations between the fee ratio and two measures of earnings management, i.e., abnormal discretionary accruals and the frequency with which reported earnings just meets or beats financial analysts' consensus forecasts. However, subsequent studies using modified research designs concluded that the results of Frankel et al. (2002) did not generalize over alternative operational measures or large versus small clients (Ashbaugh, LaFond, and Mayhew 2003; Chung and Kallapur 2003; Larcker and Richardson 2004; Reynolds, Deis, and Francis 2004). Kinney, Palmrose, and Scholz (2004) examined proprietary data from 1995-2000, and found that the association between non-audit services and the propensity to restate past financial statements depended on the category of non-audit services (see also Raghunandan, Read, and Whisenant 2003). This association was insignificant for some non-audit services (i.e., audit-related services, financial information system design and implementation, and internal audit services), significantly positive for tax services, and significantly negative for a catchall category of "unspecified" services. Only the last result raised a question about impaired independence.

Regarding link 4, which pertains to auditor independence in appearance rather than fact, Frankel et al. (2002) examined fee data in SEC proxy statements from 2001, and found a significantly negative association between abnormal stock returns and the "unexpected" component of auditors' non-audit fees. In a follow-up study, Ashbaugh et al. (2003) stressed the difficulty of isolating the market reaction for the disclosure of non-audit fees versus other disclosures in SEC proxy statements. In a test of the difference in abnormal returns over time, Ashbaugh et al. (2003) found no market reaction for disclosures of the fee ratio.

In sum, recent empirical studies examined the effects of non-audit services on auditor behavior in the reporting phase and possible financial-reporting consequences. Generally, these studies did not find a significantly negative association between non-audit services and various operational measures of auditor independence. But, the evidence from past studies is neither uniformly reliable nor complete. As studies shift the focus away from directly observing auditor behavior, and toward client or investor behavior, the evidence provides a progressively weaker basis for inferences about auditor independence (Nelson 2004). The best evidence to date comes from studies of auditors' going-concern reports. The latter evidence is incomplete, however, because of its focus on audit reports for distressed companies. Even if the conditional probability of reporting a detected misstatement is one, impairment in auditor independence occurs when the provision of non-audit services lowers the probability of detecting an existing misstatement. Finally, only the study of restatements by Kinney et al. (2004) examined nonaudit service data from the 1990s, the time that was the concern of policy makers in the formation of SOX 201. Our study is unique in its focus on auditor judgment in the dis covery phase of audit engagements prior to SOX 201.

\section{HYPOTHES ES}

Our hypotheses pertain to the association between a firm's provision of non-audit services and its auditors' risk and materiality judgments. Risk and materiality judgments are critical to audit planning. A failure to detect and adjust for existing misstatements that exceed judged materiality results in financial statements that are inconsistent with generally accepted accounting principles. Materiality judgments reasonably depend on cues such as total assets, revenue, and net income before taxes. Judged materiality affects audit cost and indirectly the audit fee, in that the cost to detect misstatements increases as the size of misstatement to be detected decreases. An upward bias in judged materiality increases audit efficiency, but more importantly decreases audit effectiveness. For a given materiality level, auditors' risk judgments represent their subjective belief that a client assertion contains a misstatement. Risk judgments reasonably depend on cues such as client industry, size, and internal controls over financial reporting. Judged risk affects audit cost and indirectly the audit fee, in that higher judged risk implies more audit effort according to the audit risk model. A down ward bias in judged risk increases audit efficiency, but more importantly decreases audit effectiveness.

A firm's provision of non-audit services might cause a bias in its auditors' risk and materiality judgments by either of two mechanisms. A psychological mechanism is motivated reasoning (Kunda 1990; see also Bazerman, Morgan, and Loewenstein 1997), whereby motivational factors unintentionally affect judgment through biased information processing that supports a preferred conclusion. Imagine an auditor who works on the audit of a client who also acquires non-audit services. If the auditor pleases the client, then there is a higher probability that the client will continue to buy both audit and non-audit services from the firm. The auditor prefers a lower audit cost, other things 
equal, in part because lower cost allows the firm to decrease its audit fee without decreasing its profit, and a lower audit fee pleases the client. When judging risk, motivated reasoning might cause the auditor to under-weigh cues such as a client's overly aggressive attitude toward financial reporting. An economic mechanism is fee dependence, whereby a desire to obtain non-audit fees from the audit client causes an intentional bias that favors the client. Both mechanisms predict a negative (positive) association between the firm's provision of non-audit services and its auditors' risk (materiality) judgments. ${ }^{3}$

When testing this prediction, however, it is important to consider the nature of non-audit services. Regarding risk judgments, non-audit services that improve an audit client's system of financial reporting indicate a lower risk of an existing misstatement. Taken by itself, a negative association between auditors' risk judgments and non-audit services that involve financial information system design and implementation does not imply impaired independence. Alternatively, a negative association between auditors' risk judgments and non-audit services that are less relevant to the audit engagement raises a question about impaired independence. An inference of impaired independence with respect to auditors' risk judgments requires the conjunction of two empirical findings: (1) a negative association between judged risk and non-audit services that involve financial information system design and implementation, and (2) a negative association between judged risk and non-audit services that are less relevant to the audit engagement.

H1. There is a negative association between auditors' risk judgments and non-audit services in each of two categories: financial information systemdesign and implementation, and other non-audit services.

Regarding materiality judgments, there is no clear justification for a positive association with non-audit services regardless of their nature. An empirical inference of impaired independence with respect to auditors' planning materiality judgments requires a positive association between judged materiality and non-audit services.

H2. There is a positive association between auditors' planning materiality judgments and non-audit services.

\section{RESULTS}

\section{Sample and Descriptive Statistics}

The sample consisted of archival data from the work papers of 78 audits that were conducted by auditors in a single practice office of a large auditing firm. One of us hand-collected the data subject to a confidentiality agreement with the firm. The agreement precluded any direct or indirect identification of the firm or its clients, but placed no restriction on our report of the results on the issue of auditor independence. The audits were for 1996-1999. Each audit involved a different client. All audit clients were manufacturing companies ( 34 high-tech, 44 bio-tech). There were 66 public companies, and 31 companies with operating profit greater than zero. No audit client in the sample received a qualified audit report, and there has been no known allegation of audit failure.

The sample included a few large clients and many smaller clients. The mean (median) values over the 78 cases were $\$ 339,576,884(\$ 21,202,217)$ for total revenue, $\$ 301,188,121 \quad(\$ 45,145,000)$ for total assets, $\$ 973,760(-\$ 3,018,176)$ for operating profit, $\$ 238,140$ ( $\$ 94,744)$ for the audit fee, and 6.06 (5.50) years for tenure, i.e., the number of years in the client-auditor relationship. For the 41 cases in which the audit client also acquired non-audit services, the mean (median) value was $\$ 241,288(\$ 52,000)$ for the non-audit fee. Non-audit personnel of the firm performed these services. The data did not include fees for income tax services, which were not banned by SOX 201.

\section{Variables}

The dependent variables were the auditors' risk and materiality judgments for revenue. The materiality judgment variable was the natural log of auditors' judgments of tolerable error for revenue. The log transformation mitigated

\footnotetext{
${ }^{3}$ Conceptually, the mechanisms differ in that motivated reasoning causes unintentional bias, whereas fee dependence causes in t en tional bias. Empirically, however, it is difficult to distinguish intentional versus unintentional bias with archival methods. Experimental methods are bet tersuited for this purpose (Nelson and $\mathrm{T}$ an 2005).
} 
the fact that the distribution of tolerable error judgments was skewed to the right. This measure was highly correlated with planning materiality judgments at the financial-statement level (Spearman $r=.99$, $p<.01$ ). Auditors at this firm routinely made separate inherent and control risk judgments at the account level on three-point scales (i.e., low, moderate, high). In this sample, the distribution for inherent risk was 46 low, 23 moderate, and 9 high. The distribution for control risk was 47 low, 23 moderate, and 8 high. Both inherent and control risk were low for 45 cases. According to the audit risk model,

Detection risk $=$ Target audit risk / client risk,

Client risk $=\mathrm{f}($ inherent risk, control risk).

There is some disagreement in the literature about the functional form of the second equation (e.g., Cushing and Loebbecke 1983). To avoid such concerns, we reduced the auditors' risk judgments to a dichotomous variable: low risk when both inherent and control risk for revenue was low (45 cases), or increased risk when either inherent or control risk for revenue was moderate or high (33 cases).

The explanatory variable pertained to the firm's provision of non-audit services to audit clients. There is some disagreement in the literature regarding the measurement of non-audit services. Kinney and Libby (2002) expressed concerns about using the fee ratio, i.e., non-audit fees divided by total fees, or ranked non-audit fees as operational measures of the economic bond between auditor and client. Another concern is that the monetary threshold for triggering fee dependence is unclear (Kinney et al. 2004), as is the threshold for triggering motivated reasoning (Kunda 1990). To avoid these concerns, we used two measures of non-audit services in our tests, and looked for convergence over the measures (Shadish, Cook, and Campbell 2002). One measure was dichotomous, equaling one when audit clients acquired non-audit services and zero otherwise. If motivated reasoning is triggered by a low threshold, then the first measure should capture its effects. The second measure was the natural log of the non-audit fee. The log transformation mitigated the fact that the distribution of non-audit fees was skewed to the right. If fee dependence monotonically increases with the magnitude of non-audit fees, then the second measure should capture its effects. ${ }^{4}$ In constructing these measures, we distinguished two categories of non-audit services: financial information system design and implementation, and other non-audit services with less audit relevance (e.g., negotiation advice and technology tracking). No client in the sample acquired non-audit services from both categories.

The control variables included client size, audit fee, ownership, industry, profit or loss, and tenure. Size was the natural log of total revenue, and audit fee was the natural log of the audit fee. The log transformations mitigated the fact that the distributions of revenue and audit fees were skewed to the right. Ownership equaled one for public companies, and zero for private companies. Industry equaled one for high-tech companies, and zero for bio-tech companies. Profit or loss equaled one for companies with an operating profit, and zero for companies with an operating loss. Tenure was the number of years in the client-auditor relationship.

Table 1 shows Spearman rank-order correlations for the dependent and independent variables. The correlations indicate that judged materiality was significantly higher for public companies, high-tech companies, larger companies, companies that paid a higher audit fee, companies with longer client-auditor tenure, companies that acquired non-audit services, and companies that paid a higher non-audit fee. Judged risk was significantly lower for high-tech companies, larger companies, companies that paid a higher audit fee, companies with longer client-auditor tenure, companies that acquired non-audit services, and companies that paid a higher non-audit fee. Ln(tolerable error were significantly less likely for public companies, companies with longer client-auditor tenure, companies that acquired non-audit services, and companies that paid a higher non-audit fee. Currently detected misstatements were significantly more likely when auditors assessed an increased risk of misstatement.

\footnotetext{
${ }^{4}$ We emphasize that our purpose in using two measures was to assess convergence, and not to distinguish empirically the mechani sms of motivated reasoning and fee dependence. 
Table 1. Spearman Rank-order Correlations

\begin{tabular}{|c|c|c|c|c|c|c|c|c|c|c|}
\hline & (2) & (3) & $(4)$ & (5) & (6) & (7) & (8) & (9) & (10) & (11) \\
\hline (1) Ownership & .13 & .06 & $.36^{* * 4}$ & $.34^{* *}$ & .20 & $.24^{*}$ & $.23^{*}$ & -.21 & $.25^{*}$ & $-.30^{* * *}$ \\
\hline (2) Industry & & .19 & $.47^{* *}$ & $.42^{* *}$ & $.29^{* *}$ & $.41^{* *}$ & $.50^{* *}$ & $-.24^{*}$ & $.38^{* *}$ & .02 \\
\hline (3) Profit/loss & & & $.35^{-\infty}$ & .20 & .14 &.$^{19}$ & $.28^{*}$ & -.22 & .15 & -.02 \\
\hline (4) $\operatorname{Ln}$ (revenue) & & & & $.77^{* *}$ & $.68^{* *}$ & $.60^{* *}$ & $.73^{* *}$ & $-.64^{* *}$ & $.73^{* *}$ & -.21 \\
\hline (5) Ln(audit fee) & & & & & $.58^{* *}$ & $.32^{* *}$ & $.54^{* *}$ & $-.28^{*}$ & $.83^{* *}$ & -.06 \\
\hline (6) Tenure & & & & & & .56 & $.64^{*}$ & -.54 & .68 & -.28 \\
\hline (7) Non-audit services & & & & & & & $.92^{* *}$ & $-.69^{* *}$ & $.46^{* *}$ & $-.53^{* *}$ \\
\hline (8) Ln(non-audit fee) & & & & & & & & $-.68^{* \ldots}$ & $.63^{\cdots \cdots}$ & $-.46^{\ldots+1}$ \\
\hline (9) Risk & & & & & & & & & $-.41^{* *}$ & $.44^{* *}$ \\
\hline (10) Ln(tolerable error) & & & & & & & & & & -.20 \\
\hline (11) Current misstatement & & & & & & & & & & \\
\hline
\end{tabular}

*Significant at $\mathrm{p}=.05$. ** Significant at $\mathrm{p}=.01$.

\section{Hypotheses Tests}

Representing the possibility of impaired independence, $\mathrm{H} 1$ states that there is a negative association between auditors' risk judgments and non-audit services in each of two categories: financial system design and implementation, and other non-audit services. Table 2 reports the results of two logistic regressions that used the auditors' risk judgments as the dependent variable. The regression in the first column tested H1 using the dichotomous measure for non-audit services, and the regression in the second column tested $\mathrm{H} 1 \mathrm{using}$ the natural log of the non-audit fee (with a value of zero when the client did not acquire non-audit services). In both regressions, the control variables were the natural logs of revenue and the audit fee, as well as ownership, industry, profit or loss, and tenure. For each regression, the table shows estimated coefficients with the corresponding Wald statistic and significance level in parentheses.

Both regressions provided similar results. Goodness of fit was high, based on the pseudo r-square statistics. Judged risk was significantly lower for larger companies, and significantly higher for companies that paid a higher audit fee, controlling for size. No other control variable had a significantly incremental effect. Regardless of the measure of non-audit services, there was a significantly negative association between non-audit services and auditors' risk judgments, but only for services involving financial information system design and implementation. For non -audit services with less audit relevance, the association with judged risk was weakly positive. Taken together, these results are inconsistent with the proposition that non-audit services generally impaired auditor independence when judging risk. Instead, the auditors lowered their risk judgments when they knew that the client acquired non-audit services leading to improved financial reporting, but did not change their risk judgments when they knew that the client had acquired non-audit services with less audit relevance.

Table 2. Logistic Regressions of Auditors' Risk Judgments on Client Attributes and Non-audit Services

\begin{tabular}{l|c|c}
\hline \multicolumn{2}{c}{ Table 2. Logistic Regressions of Auditors Risk Judgments on Client Attributes and Non-audit Services } \\
\hline Constant & I & I \\
\hline Ln(revenue) & $8.887(1.715)$ & $-2.270\left(7.273^{* *}\right)$ \\
\hline Ln(audit fee) & $-1.878\left(8.207^{* *}\right)$ & $2.270\left(5.975^{*}\right)$ \\
\hline Ownership & $1.930\left(5.638^{*}\right)$ & $2.937(3.308)$ \\
\hline Industry & $2.413(2.857)$ & $2.420(2.962)$ \\
\hline Profit/loss & $1.949(2.473)$ & $.922(.815)$ \\
\hline Tenure & $.922(.842)$ & $-.487(1.509)$ \\
\hline Non-audit services: & $-.492(1.738)$ & $-.705\left(6.944^{* *}\right)$ \\
\hline$\quad$ Financial system design and implementation & & $.027(.037)$ \\
\hline Other & $-6.059\left(6.762^{* *}\right)$ & $77.397 * *$ \\
\hline Chi-square & $.099(.005)$ & $93.6 \%$ \\
\hline Percentage correct & $74.786 * *$ & 28.881 \\
\hline Log likelihood & $92.3 \%$ & .629 \\
\hline Cox \& Snell r-square & 31.491 & .846 \\
\hline Nagelkerke r-square & .617 & .829 \\
\hline$*$ Sigificat a & & \\
\hline
\end{tabular}

*Significant at $\mathrm{p}=.05$. ** Significant at $\mathrm{p}=.01$.

Copyright by author(s); $\underline{\text { CC-B Y }}$ 
Representing the possibility of impaired independence, $\mathrm{H} 2$ states that there is a positive association between auditors' planning materiality judgments and non-audit services. Table 3 reports two ordinary least squares regressions that used the natural log of auditors' judgments of tolerable error for revenue as the dependent variable. The regression in the first column tested $\mathrm{H} 1$ using the dichotomous measure for non-audit services, and the regression in the second column tested $\mathrm{H} 1$ using the natural log of the non-audit fee (with a value of zero when the client did not acquire non-audit services). In both regressions, the control variables were the natural logs of revenue and the audit fee, as well as ownership, industry, profit or loss, and tenure. For each regression, the table shows estimated coefficients with the corresponding Wald statistic and significance level in parentheses.

Table 3. Ordinary Least Squares Regressions of Auditors' Materiality Judgments on Client Attributes and Non-audit Services

\begin{tabular}{l|c|c}
\hline & I & II \\
\hline Constant & $.966(.952)$ & $1.322(1.310)$ \\
\hline Ln(revenue) & $.137\left(2.189^{*}\right)$ & $.130\left(2.102^{*}\right)$ \\
\hline Ln(audit fee) & $.815\left(6.259^{* *}\right)$ & $.795\left(6.366^{* *}\right)$ \\
\hline Ownership & $-.249(-.986)$ & $-.248(-.991)$ \\
\hline Industry & $-.145(-.736)$ & $-.166(-.847)$ \\
\hline Profit/loss & $-.091(-.499)$ & $-.105(-.577)$ \\
\hline Tenure & $.043(1.650)$ & $.038(1.472)$ \\
\hline Non-audit services: & & $.039(1.741)$ \\
\hline$\quad$ Financial system design and implementation & $.308(1.256)$ & $.036(1.181)$ \\
\hline$\quad$ Other & $.397(1.284)$ & $31.052^{* *}$ \\
\hline F ratio & $30.502^{* *}$ & .757 \\
\hline Adjusted r-square & .754 & \\
\hline
\end{tabular}

*Significant at $\mathrm{p}=.05$. **Significant at $\mathrm{p}=.01$.

Both regressions provided similar results. Goodness of fit was high, based on adjusted r-square. Judged materiality was significantly higher for larger companies after controlling for audit fee, and for companies that paid a higher audit fee, after controlling for size. Explaining the separate effects on the auditors' materiality judgments of size and the audit fee is problematic, given the high correlation between these variables (Spearman $r=.77, p<.01$ ). No other explanatory variable had a significantly incremental effect. There was an insignificant association between non-audit services and auditors' materiality judgments, regardless of the measure of non-audit services and regardless of the nature of non-audit services. These results are inconsistent with the proposition that non-audit services generally impaired auditor independence when judging planning materiality.

\section{Currently Detected Misstatements}

To examine further effects of non-audit services, Table 4 reports two logistic regressions that used the presence versus absence of currently detected misstatements as the dependent variable. The regression in the first column used the dichotomous measure for non-audit services, and the regression in the second column used the natural $\log$ of the non-audit fee (with a value of zero when the client did not acquire non-audit services). In both regressions, the control variables were the natural logs of revenue, judged tolerable error, and the audit fee, as well as ownership, industry, profit or loss, tenure, and judged risk. For each regression, the table reports estimated coefficients with the corresponding Wald statistic and significance level in parentheses. Both regressions provided similar results. Goodness of fit was moderate, based on the pseudo r-square statistics. Currently detected misstatements were significantly more likely in high-tech companies. No other control variable had a significantly incremental effect. There was a significantly negative association between non-audit services and currently detected misstatements, but only for services involving financial information system design and implementation. Given the inclusion of the auditors' risk and materiality judgments as control variables, the incremental effect for non-audit services involving financial information system design and implementation suggests real improvement in the client's accounting systembecause of these services. 
Table 4. Logistic Regressions of the Presence versus Absence of Currently

Detected Misstatements on Client Attributes, Auditors' Planning Judgments, and Non-audit Services

\begin{tabular}{|c|c|c|}
\hline & $\mathbf{I}$ & II \\
\hline Constant & $-8.062(2.184)$ & \\
\hline Ln(revenue) & $.092(.104)$ & $.066(.052)$ \\
\hline Ln(tolerable error) & $-.584(1.170)$ & $-.576(1.150)$ \\
\hline Ln(audit fee) & $1.045(1.852)$ & $1.253(2.249)$ \\
\hline Ownership & $-1.711(3.004)$ & $-1.765(3.167)$ \\
\hline Industry & $1.851\left(3.830^{*}\right)$ & $1.832(3.803 *)$ \\
\hline Profit/loss & $.635(.557)$ & $.732(.709)$ \\
\hline Tenure & $.136(.893)$ & $.131(.833)$ \\
\hline Risk & $.327(.082)$ & $.268(.052)$ \\
\hline \multicolumn{3}{|l|}{ Non-audit services: } \\
\hline Financial system design and implementation & $-6.117\left(8.605^{* *}\right)$ & $-.535(9.389 * *)$ \\
\hline Other & $-2.358(2.570)$ & $-.216(2.487)$ \\
\hline Chi-square & $46.700 * *$ & $47.008 * *$ \\
\hline Percentage correct & $84.6 \%$ & $85.9 \%$ \\
\hline Log likelihood & 52.596 & 52.288 \\
\hline Cox \& Snell r-square & .450 & .453 \\
\hline Nagelkerke r-square & .626 & .629 \\
\hline
\end{tabular}

*Significant at $\mathrm{p}=.05 .{ }^{*}$ Significant at $\mathrm{p}=.01$.

\section{CONCLUSION}

This study contributes to the literature on auditor independence by examining the effects of a firm's provision of non-audit services on its auditors' planning judgments, based on archival data from the late 1990s prior to the ban of such services by SOX 201. The results revealed a significantly negative association between the firm's provision of non-audit services and its auditors' risk judgments, but only for services involving financial information system design and implementation. A plausible explanation is that these services produced real improvement in the client's financial reporting system, leading auditors to lower their risk judgments. In contrast, the auditors did not change their risk judgments when the firm provided non-audit services with less audit relevance. Also, non-audit services had an insignificant effect on the auditors' materiality judgments. Based on our sampled observations and our tests, we conclude that non-audit services did not cause an inappropriate bias in auditor judgment, contrary to the belief apparently held by policy makers in the formation of SOX 201.

Relative to past studies on auditor independence, our study is unique in its focus on auditors' risk and materiality judgments in the planning phase of audit engagements. Most past studies foc used on the association of non-audit services with audit reports or with possible financial-reporting consequences of impaired independence. Our study instead tested whether non-audit services affected audit planning and the probability of detecting existing misstatements, recognizing that audit quality depends on the probability of detecting existing misstatements as well as the probability of reporting detected misstatements. Also, most past studies relied on data that was available because of the SEC disclosure rule of 2000. It is unclear whether conclusions based on such data generalize to the earlier time that was the concern of policy makers in the formation of SOX 201, because auditors and their clients may have adapted their behavior once the rule was in effect. Only the study of restatements by Kinney et al. (2004) examined non-audit service data from the 1990s. They found that non-audit services involving financial information system design and implementation had a beneficial but insignificant effect on financial-reporting quality as measured by the propensity to restate in subsequent periods. Our direct focus on auditor judgment provided complementary and less noisy evidence for an empirical inference about auditor independence prior to the ban by SOX 201.

We acknowledge the limitations of our sample. Our sample represented one practice office of a large firm with a concentration of high-tech and bio-tech companies. It is an empirical issue as to whether our conclusions would generalize to other samples from the 1990s. We also acknowledge that archival methods have limited ability to refute alternative explanations, which motivates related experimental studies (Nelson and Tan 2005). By manipulating carefully designed treatments, experimental methods would permit clearer contrasts regarding the 
audit relevance of non-audit services and provide a better basis for distinguishing intentional and unintentional bias. For example, Kadous, Kennedy and Peecher (2003) effectively used experimentation to test hypotheses about the role of motivated reasoning in auditors' decisions to accept clients' aggressive reporting methods. Of course, it is unclear whether the results of any new experiments would generalize to the earlier time that was the concern of policy makers in the formation of SOX 201.

Going forward, we encourage regulators to base policy on relevant empirical research in the tradition of normative positive economics. According to Levitt (2002), a group of politicians who opposed a proposed ban on non-audit services requested that the SEC produce empirical evidence about the adverse effects of non-audit services on auditor independence. In our view, the politicians' request was appropriate and timely. Researchers can provide relatively objective evidence about empirical propositions that are relevant to policy, given access to data under conditions that protect confidentiality, as with our study. A likely benefit would be less concern about apparent conflicts of interest, and a positive basis for effective and efficient regulation.

\section{AUTHOR INFORMATION}

Tim Kizirian, Ph.D., Profes sor of Accounting, Chico State University, USA. Email: TKizirian@csuchio.edu.

Ruben Sargsyan, Ph.D., Assistant Profes sor of Economics, Chico State University, USA.

DATA AVAILAB ILITY: Contact the first author.

\section{REFERENCES}

Abdel-khalik, A. R. and B. B. Ajinkya. 1979. Empirical research in accounting: A methodological viewpoint. Sarasota: American Accounting Association.

Ashbaugh, H., R. LaFond, and B. Mayhew. 2003. Do non-audit services compromise auditor independence? Further evidence. The Accounting Review 78: 611-639.

Bazerman, M., K. Morgan, and G. Loewenstein. 1997. The impossibility of auditor independence. Sloan Management Review 38: $89-94$.

Blaug, M. 1992. The methodology of economics: Or how economists explain. Cambridge: Cambridge University Press.

Chung, H., and S. Kallapur. 2003. Client importance, non-audit services, and abnormal accruals. The Accounting Review 78: 931-955.

Cushing, B., and J. Loebbecke. 1983. Analytical approaches to audit risk: A survey and analysis. Auditing: A Journal of Practice and Theory 3: 23-41.

DeAngelo, L. 1981. Auditor size and audit quality. Journal of Accounting and Economics 3: 183-199.

DeFond, M., K., Raghunandan, and K. Subramanyam. 2002. Do non-audit service fees impair auditor independence? Evidence from going concern audit opinions. Journal of Accounting Research 40: 1247-1274.

Frankel, R., M. Johnson, and K. Nelson. 2002. The relation between auditors' fees for non-audit services and earnings management. The Accounting Review 77: 71-105.

Friedman, M. 1953. Essays in positive economics. Chicago: University of Chicago Press.

Geiger, M. and D. Rama. 2003. Audit fees, non-audit fees, and auditor reporting on stressed companies. Auditing: A Journal of Practice \& Theory 22: 53-69.

Healy, P. and K. Palepu. 2003. The fall of Enron. Journal of Economic Perspectives 17: 3-26.

Kadous, K., J. Kennedy, and M. Peecher. 2003. The effect of quality assessment and directional goal commitment on auditors' assessment of client-preferred accounting methods. The Accounting Review 78: 759-778.

Kinney, W., and R. Libby. 2002. Discussion comments on 'The relation between auditors' fees for non-audit services and earnings management.' The Accounting Review 77: 107-114.

, V. Palmrose, and S. Scholz. 2004. Auditor independence, non-audit services, and restatements: Was the U.S. government right? Journal of Accounting Research 42: 561-588.

Kunda, Z. 1990. The case for motivated reasoning. Psychological Bulletin 108: 480-498.

Larcker, D., and S. Richardson. 2004. Fees paid to audit firms, accrual choices, and corporate governance. Journal of Accounting Research 42: 625-658.

Levitt, A. 2000. Renewing the covenant with investors. Speech at The New York University Center for Law and Business, New York.

2002. Take on the street: How to fight for your financial future. New York: Random House.

Nelson, M. 2004. A review of experimental and archival conflicts-of-interest research in auditing. In D. A. Moore, D. M. Cain, 
G. Loewenstein and M. H. Bazerman (Eds.), Conflicts of interest: Problems and solutions in law, medicine, and organizational settings. Cambridge: Cambridge University Press. and H. Tan. 2005. Judgment and decision making research in auditing: A task, person, and interpersonal interaction perspective. Auditing: A Journal of Practice \& Theory (forthcoming).

Panel on Audit Effectiveness. 2000. Report and recommendations. Stamford, CT: Public Oversight Board.

Raghunandan, K., W. Read, and J. Whisenant. 2003. Initial evidence on the association between non-audit fees and restated financial statements. Accounting Horizons 17: 223-234.

Reynolds, J., D. Deis, and J. Francis. 2004. Professional service fees and auditor objectivity. Auditing: A Journal of Practice \& Theory 23: 29-52.

Securities and Exchange Commission. 2000. Final rule: Revision of the commission's auditor independence requirements. Washington, D.C.: Government Printing Office.

Shadish, W., T. Cook, and D. Campbell. 2002. Experimental and quasi-experimental designs for generalized causal inference. Boston: Houghton Mifflin. 


\section{NOTES}

